Ivar Wendling', José Alfredo Sturion', Cristiane Aparecida Fioravante Reis', Carlos André Stuepp ${ }^{2}$, Martha Lucía Peña Peña ${ }^{2}$

\title{
INDIRECT AND EXPEDITE ASSESSMENT OF Ilex paraguariensis COMMERCIAL YIELD
}

Keywords:

Erva-mate

Indirect methods

Biomass estimation

Visual estimate

Morphotype

Histórico:

Recebido 20/06/2016

Aceito 13/07/2016

Palavras chave: llex paraguariensis

Metodos indiretos

Estimativa de biomassa

Estimativa visual Morfotipos

Correspondência: ivar.wendling@embrapa.br

DOI:
ABSTRACT: Commercial biomass production is one of the main indicators for selecting erva-mate (Ilex paraguariensis) progenies and clones. Traditional techniques to obtain such information depend on the harvesting of trees and there are some limitations involved, such as high cost and reduced convenience. Thus, in our research we evaluated the efficiency of indirect methods through commercial biomass estimation and score of productivity according to the different provenances, gender and morphotypes. In a provenances and progenies trial installed in 1997, two methodologies of visual analysis were evaluated in August 2015 (two years after the last harvest). For that reason, five expert evaluators determined, for each plant, an estimate of the commercial biomass $(\mathrm{kg})$, and a grade, based on a score of productivity (0-10). In order to assess the productivity using traditional techniques, all plants were pruned and their commercial biomass (leaves and fine branches smaller than $7 \mathrm{~mm}$ diameter) were harvested and weighed $\left(\mathrm{kg} \cdot \mathrm{plant}^{-1}\right)$. The evaluations were performed in a randomized-block experiment with five repetitions, seven different provenances and 126 progenies, totaling 5,292 evaluated plants. The methods utilized were effective to estimate the commercial biomass. The evaluators showed accuracy, expressing efficiently the largest productivity obtained when comparing the means of provenances, plants gender and morphotypes. The highest correlations were observed in the general analysis of the means, and the estimation of commercial biomass was considered the best methodology for estimating the commercial biomass assessed in adult erva-mate plants.

\section{METODOLOGIA PARA AVALIAÇÃO EXPEDITA E INDIRETA DA PRODUTIVIDADE COMERCIAL DE ERVA-MATE}

RESUMO: A produção de biomassa comercial é uns dos principais indicadores para seleção de progênies e clones de erva-mate. Técnicas tradicionais para se obter tais informações dependem da colheita das árvores e apresentam, dentre outras limitações, elevado custo e reduzida praticidade. Assim, objetivou-se avaliar a eficiência de métodos indiretos, por meio de estimativa de biomassa comercial e escore de produtividade em função de diferentes procedências, sexo e morfotipos. Em um teste de progênies e procedências instalado em 1997, foram avaliadas em agosto de 2015 (dois anos após a última colheita) duas metodologias de análise visual. Para tanto, participaram cinco avaliadores treinados que determinaram, para cada planta, uma estimativa de biomassa comercial (kg), e uma nota, com base em um escore de produtividade (0-10). Para avaliação da produtividade pelas técnicas tradicionais, todas as plantas foram podadas e tiveram sua biomassa comercial (folhas e ramos finos menores de $7 \mathrm{~mm}$ de diâmetro) colhida e avaliada por meio de pesagem (Kg·planta-1). As avaliações foram realizadas em experimento instalado em blocos ao acaso, com cinco repetições, sete procedências e 126 progênies, totalizando 5292 plantas avaliadas. Os métodos avaliados foram eficientes na estimativa da biomassa comercial. Os avaliadores apresentaram boa acuidade nas estimativas, expressando de forma eficiente a maior produtividade determinada por comparação de médias entre as procedências, sexo das matrizes e morfotipos. As maiores correlações foram verificadas na análise geral das médias e a estimativa de biomassa comercial é a melhor metodologia para estimar a biomassa comercial aferida em plantas adultas de erva-mate.

' Embrapa Florestas - Colombo, Paraná, Brasil

2 Universidade Federal do Paraná - Curitiba, Paraná, Brasil 


\section{INTRODUCTION}

Erva-mate (Ilex Paraguariensis) (Aquifoliaceae) has a great economic, environmental, social and cultural importance in the southern region of Brazil, as well as in Argentina and Paraguay (STURION; RESENDE, 20I0). The crop of erva-mate is undoubtedly one of the most promising, as long as practiced in a suitable technological level (WENDLING, 2004).

The importance of erva-mate is increasing Brazilian silviculture, considering the growing interest in products from that species. Among these, many of them related to food, pharmaceutical and health sciences discover and bring day after day more information that can improve its production system and bring new forms of consumption (CARDOZO JUNIOR; MORAND, 2016; RAMIREZ-MARES et al., 2016; SANTOS et al., 2015; SILVEIRA et al., 2016).

Considering the several aspects related to the improvement of the species, the effect of nutritional status of different provenances (OLIVA et al., 20I4) and their respective progenies (STURION; RESENDE, 2005; RAKOCEVIC et al., 2005), the sexual dimorphism (male and female plants, (RAKOCEVIC et al., 20II; STURION; RESENDE, 2010), the cultivation system (in consortium or homogenous) (CARON et al., 20I4) and the cultivation type have showed a strong influence on leaf mass production (RAKOCEVIC et al., 2007; 2009). In a similar way, some morphological variations, mainly related to leaves (BASTOS et al., 20I4; BORILLE et al., 2005; VALDUGA et al., 2016) were described in Brazil (REISSMANN et al., 2003) and Argentina (JANSSENS; SCHERER, 20I I), however, they were not still linked to the productivity of the species.

Although the selection of plants of high-yield crop should be based on genetic values of each plant, the proof of the actual value of the genetic material is based on their phenotypic values (STURION; RESENDE, 2010). Thus, the use of indirect methods of evaluation as a selection criterion may be an alternative for the genetic improvement of characteristics related to erva-mate biomass productivity, mainly by its potential to reduce the evaluation time and the expenses of traditional measurement process.

Considering a sensorial analysis, the comprehension (visual) does not depend exclusively on the senses, but also on the interpretation and understanding of the elements captured, i.e., the experience of evaluators (FERREIRA et al., 2016). Considering erva-mate, wich commercial goal is the production of leaves and fine stems (smaller than $7 \mathrm{~mm}$ )
(SANTIN et al., 20I5), the main characteristics that may lead the evaluators to misperceive the productivity level are the green biomass, defoliation and the type and architecture of the branches (STURION; RESENDE, 2010). However, there is no description of visual estimation methodologies developed for forest species in the literature.

Similar methodologies, still less diffused in perennial species, have been applied successfully in agronomic cultivars, usually based on visual identification of plants with superior characters, which requires a higher ability of the evaluator (CUNHA et al., 2005; MENEZES JUNIOR et al., 2008; RIBEIRO et al., 20I0). In this way, the use of visual scores in selection programs and its correlation with the productivity linked to biological characters like gender, provenances, progenies and morphotypes, may be an excellent alternative to support the selection process of erva-mate progenies and clones. In addition, it could be an important tool to estimate the erva-mate productivity by crop producers.

Based on the hypothesis that the biomass of ervamate plants can be determined by a visual estimate, this study evaluated the estimation methods of commercial biomass and scores of productivity according to the different provenances, genders and morphotypes, in order to identify the best methodology to assist the selection of superior genetic material.

\section{MATERIAL AND METHODS}

The experiment was stablished in Ivaí, state of Paraná, Brazil $\left(25^{\circ} 0 \mathrm{l}\right.$ 'S, $50^{\circ} 47^{\prime} \mathrm{W}$ and $650-750 \mathrm{~m}$ altitude) in March 1997, as a provenance and progeny trial. Progenies had five Brazilian geographical origins (provenances), as follows: Ivaí (PR) (progenies I to 25), Colombo (PR) (progenies 26 to 50), Barão de Cotegipe (RS) (progenies 5I to 75), Quedas do Iguaçú, PR, (progenies 76 to I00), Pinhão (PR) (progenies I0I to I25), Antônio Olinto (PR) (progenies I26 to I50) and Cascavel (PR) (progenies I5I to I75) (CARDOZO JUNIOR et al., 2010). The Ivaí climate is Cfb-type, mesothermal humid subtropical. Warm summers and infrequent frosts occur in this region, and there is a tendency for rain concentration during the summer and no well-defined dry season (IAPAR, 2016). The soil is dystrophic red latosol (Rhodic Hapludox) comprising $72 \%$ of clay and $4 \%$ slope (SANTOS et al., 2006).

The experiment was arranged in a randomizedblock design in 10 repetitions with six plants in $3 \times 2 \mathrm{~m}$ spacing. Progenies were randomized without hierarchic arrangement within each geographical origin. We 
evaluated five blocks (replications), contemplating seven provenances and 126 progenies, with a total of 5,292 evaluated plants.

In August 2015 (18.5-year-old plants, two years after the last harvest) visual scores, attributed to the structure of the erva-mate canopy, were determined by five trained evaluators, following two methodologies: I) determination of a value related to the estimation of commercial biomass of each plant, based on the experience of each evaluator and previous training; 2) determination of productivity score with the establishment of a score related to the productivity of each plant, ranging from 0 (plants with low productivity) to 10 (plants with high productivity).

Visual evaluations (commercial biomass and productivity score) were performed individually for each plant, by five expert evaluators, with high-level knowledge in erva-mate silviculture. In order to get a better accuracy when determining the scores, the evaluators received training in using the tradicional measurement through the weighing of the total biomass of 10 ervamate plants, representing all the evaluated morphotypes. The evaluators were dismissed in each block at different moments, with an interval of 10 minutes, in order to have no contact between them throughout the assessment.

Some parameters were also observed by the evaluators at the time of the set of visual biomass estimations, among which, height, diameter, amplitude (scope) and density of the canopy, always compared to the plants within the same plot (progeny). All those characteristics assign erva-mate plants a greater productive area. In the case of the canopy density, it assigns a better relationship between the commercial and residual biomass, which is also an excellent leaf falling-off indicator, a preponderant factor in productivity of that specie.

After visual evaluation, trained employees, following the usual methodology, which includes the total harvest of the canopy of each plant, harvested the plants in their entirety. After the pruning of all plants branches, commercial biomass (leaves and branches under $7 \mathrm{~mm}$ ) was weighed with the aid of a mechanical scale. That procedure was performed in all plants of the experiment and dead plants were not considered in the analyses for not having commercial biomass.

For a better identification of the factors which affect the experts visual accuracy, the effects of different provenances (origin of genetic material), gender (male and female) and morphotypes were analyzed, which can be gathered into six groups, adapted from Reissmann et al. (2003) (Table I, Figure I).
TABLE I Characterization of morphotypes observed in different erva-mate progenies.

\begin{tabular}{|c|c|}
\hline Morphotype & Definition \\
\hline $\begin{array}{l}\text { Yellow } \\
\text { (Y) }\end{array}$ & $\begin{array}{l}\text { Leaves with a light hue and principal and secondary } \\
\text { veins in yellowish hue (REISSMANN et al., 2003) }\end{array}$ \\
\hline $\begin{array}{l}\text { Gray } \\
(\mathrm{G})\end{array}$ & $\begin{array}{l}\text { Leaves with greenish-gray hue and the veins are not } \\
\text { so yellowish (REISSMANN et al., 2003) }\end{array}$ \\
\hline $\begin{array}{l}\text { Sassafrás } \\
\qquad(\mathrm{S})\end{array}$ & $\begin{array}{l}\text { Leaves with dark green hue and veins with lighter } \\
\text { hue. Characterized by the glossy appearance of } \\
\text { limbo in the adaxial face (Reissmann et al., 2003) }\end{array}$ \\
\hline $\begin{array}{l}\text { Dark green } \\
\qquad(\mathrm{DaG})^{*}\end{array}$ & $\begin{array}{l}\text { Leaves with intense green hue. Characterized by } \\
\text { absence of brightness of leaf in the adaxial face }\end{array}$ \\
\hline $\begin{array}{l}\text { Dull green } \\
\text { (DuG)* }\end{array}$ & $\begin{array}{l}\text { Leaves with green hue opacities. Characterized by } \\
\text { absence of brightness of leaf in the adaxial face. }\end{array}$ \\
\hline $\begin{array}{l}\text { Peludinha } \\
\text { (P)* }\end{array}$ & $\begin{array}{l}\text { Characterized by the presence of pilosity in the } \\
\text { adaxial face }\end{array}$ \\
\hline
\end{tabular}

* Morphotypes presented for the first time.

The treatment variances were evaluated for homogeneity by Bartlett's test, and the variables that showed significant differences by the $\mathrm{F}$ test had their averages compared by Tukey test at $5 \%$ probability. To check the correlation between the measured variables, Pearson correlation analysis was applied $(p<0.0 I$ and $p<0.05)$.

\section{RESULTS AND DISCUSSION}

Estimation of commercial biomass in adult plants of erva-mate is a complex activity, regardless of the method applied; all of them have limitations and are susceptible to errors. On the other hand, they can produce relevant results, as long as their limitations are previously known and analyzed.

Direct methods imply determinations (real measurement made directly in the biomass), due to the fact that trees of a plot are cut and its components separated and weighed, followed by an extrapolation of the sample for the total area of interest (SILVEIRA et al., 2008). The estimation of biomass by indirect methods consists of correlating it with some variable easy to obtain and which does not require the destruction of the plant material (RIBEIRO et al., 20I0).

Validation of a non-destructive methodology, i.e., which does not depend on the final harvest to determine productivity in erva-mate, can bring significant breakthrough for the species silviculture, as well as the productive area. The reduction of the evaluation time, the ease of implementation and cost reduction are some of the benefits of these methods.

With regard to the indirect method used, both the estimation of commercial biomass and the establishment of productivity score (note) showed great variation among the five evaluators. The averages of the commercial biomass estimation were very similar to the 

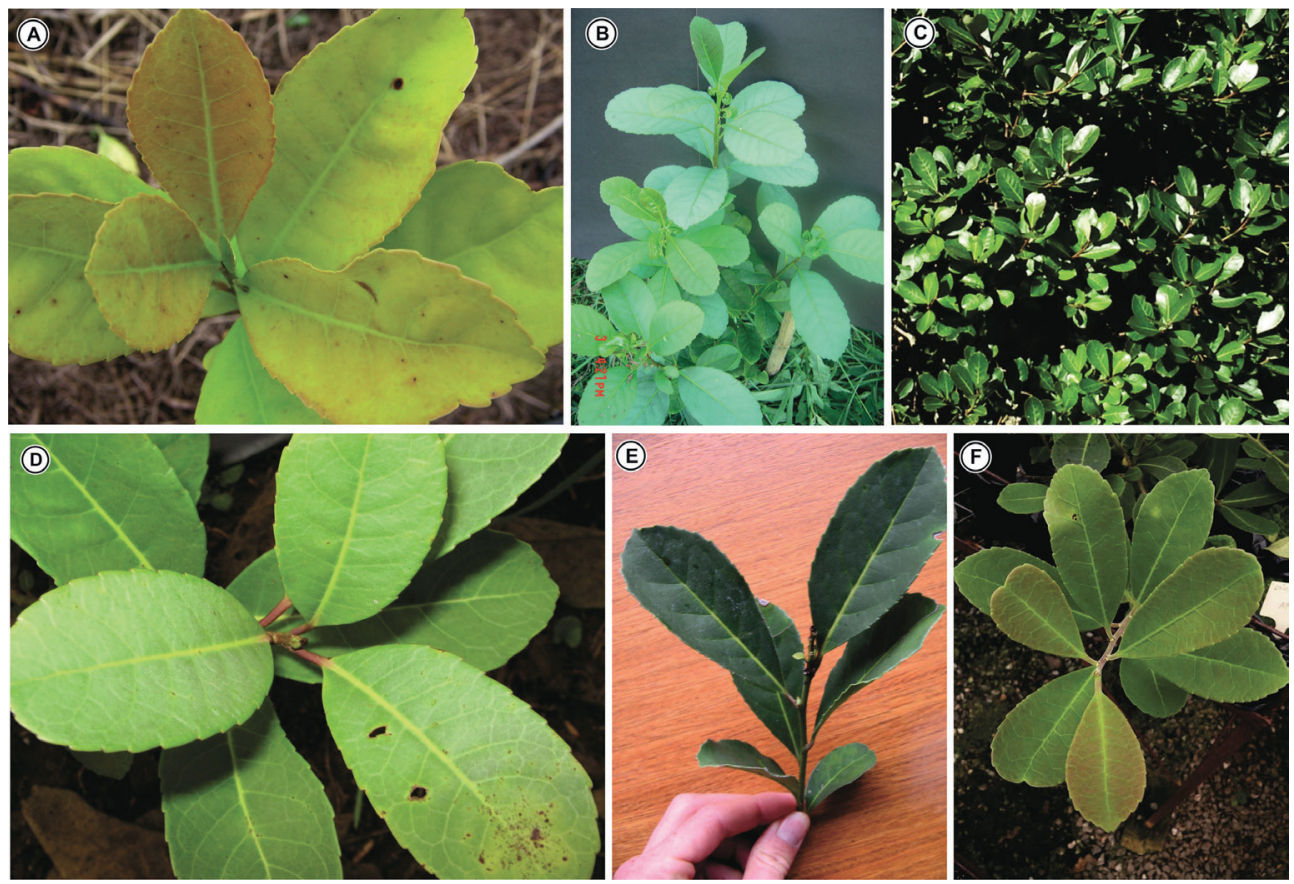

FIGURE I General characterization of the morphotypes evaluated in provenances and progenies trial of Ilex paraguariensis. Where, yellow $(A)$, gray $(B)$, sassafrás $(C)$, dull green $(D)$, dark green $(E)$, peludinha $(F)$.

measured commercial biomass $\left(\mathrm{kg} \cdot\right.$ plant $\left.^{-1}\right)$ obtained by the direct method, except for evaluator 2 .

Concerning the estimation of the grade, it is more evident the variation among the evaluators, with a considerable difference assigned to evaluator I (Figure 2). Differently from the estimation of biomass, the score of productivity must not necessarily be similar to the average, but it must represent the average in a less extensive scale $(0-10)$, once the productivity in ervamate plants may exceed $50 \mathrm{~kg} \cdot$ plant $^{-1}$.

The great variety of erva-mate cultivation systems may limit the use of visual methodologies, once the high heterogeneity of plantations limits the setting of general characteristics, with a lot of ramifications types and canopy architecture, density and morphotypes (REISSMANN et al., 2003; JANSSENS; SCHERER, 20I I), common in native stands and seminal plantations. This way, it is essencial to train the evaluators so they can be able to implement in their assessment the same pre-defined criteria for all samples, getting more reliable results.

The results for the correlation among commercial biomass measured $(C B)$, commercial biomass estimation (CBE) and productivity score (EP) appeared highly significant, independent of the evaluator (Table 2). The high correlation observed among the variables studied suggests that, besides the use of direct methods (traditional weighing of commercial biomass), erva-mate productivity can also be evaluated by nondestructive indirect methods, as presented in this study.

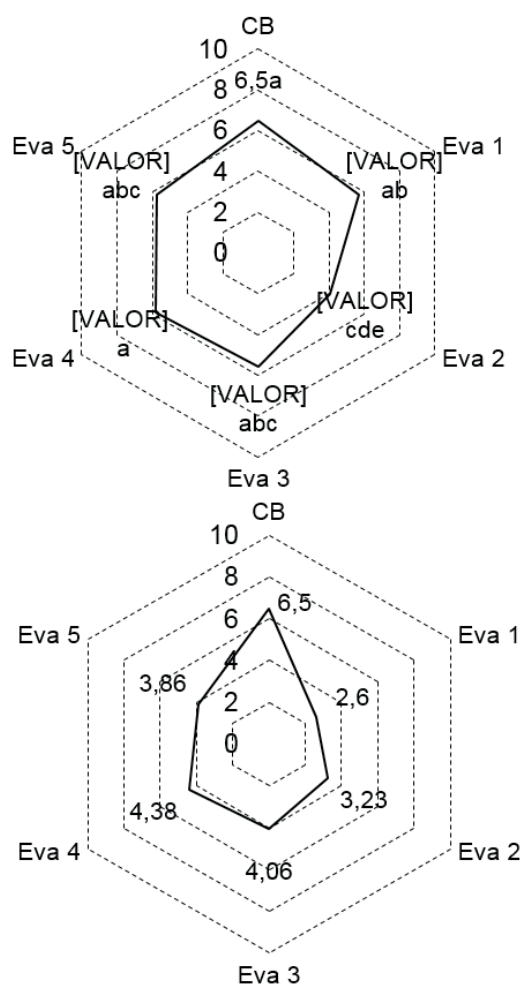

FIGURE 2 General averages for commercial biomass measured $\left(\mathrm{kg} \cdot\right.$ plant $\left.^{-1}\right)$, commercial biomass estimation (a) and productivity score (b) in a erva-mate provenances and progenies trial located in the Ivaí, PR, Brazil. Average numbers followed by the same letter in "case a" do not differ from each other by Tukey test at $5 \%$ probability. 
TABLE 2 Correlation between commercial biomass measured (CB), commercial biomass estimation (CBE) and score of productivity (EP) in an erva-mate provenances and progenies trial located in the Ivaí, PR, Brazil.

Eva I Eva 2 Eva 3 Eva 4 Eva 5 Estimated biomass CBXCBE 0.95 ** 0.92 ** 0.76 *** 0.88 ** 0.74 ** Productivity score CBXEP $0.94 * 0.89 *$ * 0.8 I ** 0.86 * 0.76 ** * and ** significant at $5 \%$ and $1 \%$ error probability, respectively, and "ns" not significant at $5 \%$ of probability by the $F$ test.

The high variation between commercial biomass (CB) for the seven evaluated provenances is a consequence of the high genetic variability of the species. The largest values for average productivity in $\mathrm{kg} \mathrm{plant}^{-1}$ were verified at the provenances of Quedas do lguaçu (PR), Barão de Cotegipe (RS), Ivaí (PR) and Cascavel (PR), differing significantly from the others (Table 3). In a similar way, the provenances which presented the highest values for measured commercial biomass (CB) also had the greatest values for commercial biomass estimation and productivity score, confirming the visual acuity of evaluators in biomass estimation (productive characteristics of the species) and the efficiency of the used method for estimation of commercial biomass for adult erva-mate.

The correlation between measured commercial biomass (CB), commercial biomass estimation (CBE) and productivity score (PS) is higher in provenances of Pinhão (PR) and Antonio Olinto (PR), presenting the last positive correlation for all evaluators, independent of the applied methodology (Table 4). The high correlation in the provenance of Antônio Olinto (PR), despite not representing the extremes of productivity, is probably related to the greater regularity among the evaluated plants.

Despite the higher commercial biomass productivity of female plants, significant differences were not found between plants of different sexes (Table 5). Sturion et al. (1995) working with erva-mate noticed that female plants produce $15.1 \%$ more leaf mass than male plants. However, it is possible to perceive that the estimates of commercial biomass for male plants tended to be similar to the measured commercial biomass when compared to those of the female sex. This difference between sexes has been common in dioecious forestry species, and has been explained by the biological, biochemistry and phenotypic variation between sexes, resulting from the allocation of specific resources to supply each sex demands (ROBINSON et al., 2014; RAKOCEVIC et al., 2007; 2009).

The environment of cultivation, especially the conditions of high or low luminosity and the stage of development can interfere on the sexual expression (RAKOCEVIC et al., 20II). Height and diameter have been the phenotypic characteristics more used as indicators to analyze these changes related to sex, considering that the vegetative vigor is the result of a greater ability to adaptation (PETZOLD et al., 20/3).

TABLE 4 Correlation between measured commercial biomass ( $\mathrm{CB})$, commercial biomass estimation (CBE) and productivity score (PS) for seven different provenances of erva-mate located in the Ivaí, PR.

\begin{tabular}{|c|c|c|c|c|c|c|c|}
\hline Provenances & I & 2 & 3 & 4 & 5 & 6 & 7 \\
\hline Evaluators & \multicolumn{7}{|c|}{ Commercial biomass (CB) } \\
\hline \multirow{5}{*}{$\mathrm{CBE}$} & Eva I 0.88 * & 0.84 ns & $0.77^{\text {ns }}$ & $0.83^{\text {ns }}$ & 0.97 *** & $0.96 * *$ & $0.96 *$ \\
\hline & Eva 20.40 ns & 0.87 ns & $0.19^{\text {ns }}$ & $0.60 \mathrm{~ns}$ & $0.91 *$ & $0.99 * *$ & 0.77 \\
\hline & Eva 30.27 ns & 0.54 ns & $-0.21^{\text {ns }}$ & $-0.20^{\text {ns }}$ & $-0.02^{\text {ns }}$ & $0.93 *$ & -0.34 \\
\hline & Eva $40.53^{\text {ns }}$ & $0.70^{\mathrm{ns}}$ & -0.01 ns & $0.00 \mathrm{~ns}$ & 0.22 ns & $0.94 *$ & -0.10 \\
\hline & Eva 50.09 ns & $0.50^{\mathrm{ns}}$ & $-0.4 I^{\text {ns }}$ & $-0.40^{\mathrm{ns}}$ & -0.20 ns & $0.94 *$ & -0.61 \\
\hline \multirow{5}{*}{ PS } & Eva I $0.53^{\text {ns }}$ & $0.77^{\mathrm{ns}}$ & $0.76^{\text {ns }}$ & $0.77^{\text {ns }}$ & $0.98 * *$ & $0.99 * *$ & $0.88^{*}$ \\
\hline & Eva $20.08^{\text {ns }}$ & $0.76^{\mathrm{ns}}$ & $0.1 I^{\text {ns }}$ & $0.56^{\mathrm{ns}}$ & 0.64 ns & $0.89 *$ & 0.81 \\
\hline & Eva 30.30 ns & 0.62 ns & $-0.1 I^{\text {ns }}$ & $-0.05^{\text {ns }}$ & $0.12^{\text {ns }}$ & $0.95 *$ & -0.13 \\
\hline & Eva 40.52 ns & 0.69 ns & 0.03 ns & 0.02 ns & $0.16^{\mathrm{ns}}$ & $0.93 *$ & -0.05 \\
\hline & Eva $50.19^{\text {ns }}$ & $0.47^{\text {ns }}$ & -0.50 ns & $-\left.0.4\right|^{\mathrm{ns}}$ & $-0.21^{\mathrm{ns}}$ & $0.96 *$ & -0.63 \\
\hline
\end{tabular}

* and ** significant at $5 \%$ and $1 \%$ error probability, respectively, and "ns" not significant at $5 \%$ of probability by the $\mathrm{F}$ test. Where: provenance I = Ivaí (PR); 2 = Colombo (PR); 3 = Barão de Cotegipe (RS); 4 = Quedas do Iguaçú, PR; 5 = Pinhão (PR); 6 = Antônio Olinto (PR); 7 = Cascavel (PR).

TABLE 3 Measured commercial biomass (CB), commercial biomass estimation and productivity score for seven different provenances of erva-mate located in Ivaí, PR.

\begin{tabular}{|c|c|c|c|c|c|c|c|c|c|c|c|}
\hline \multirow{2}{*}{ Provenance } & \multirow{2}{*}{$\frac{\text { Commercial biomass }^{\mathrm{kg} \cdot \text { plant }^{-1}}}{}$} & \multicolumn{5}{|c|}{ Estimated biomass } & \multicolumn{5}{|c|}{ Productivity score } \\
\hline & & Eva I & Eva 2 & Eva 3 & Eva 4 & Eva 5 & Eva I & Eva 2 & Eva 3 & Eva 4 & Eva 5 \\
\hline I & $8.38 \mathrm{a}$ & $7.18 \mathrm{a}$ & $4.92 \mathrm{a}$ & $6.36 \mathrm{a}$ & $6.98 \mathrm{ab}$ & $6.52 \mathrm{a}$ & $3.23 \mathrm{a}$ & $3.77 \mathrm{a}$ & $4.57 \mathrm{abc}$ & $5.03 \mathrm{abc}$ & $4.22 \mathrm{a}$ \\
\hline 2 & $1.86 \mathrm{c}$ & $2.09 c$ & $\mathrm{I} .54 \mathrm{c}$ & $2.27 \mathrm{~b}$ & $2.48 \mathrm{~d}$ & $1.91 \mathrm{~b}$ & $1.01 \mathrm{c}$ & $1.34 \mathrm{c}$ & $1.72 \mathrm{~d}$ & $1.81 \mathrm{~d}$ & $\mathrm{I} .34 \mathrm{~b}$ \\
\hline 3 & $8.75 a$ & $7.23 \mathrm{a}$ & $5.12 \mathrm{a}$ & $6.6 \mathrm{I} \mathrm{a}$ & $7.25 \mathrm{ab}$ & $6.86 \mathrm{a}$ & $3.27 \mathrm{a}$ & $3.98 \mathrm{a}$ & $4.74 \mathrm{abc}$ & $5.31 \mathrm{abc}$ & $4.47 \mathrm{a}$ \\
\hline 4 & $8.96 \mathrm{a}$ & $7.6 \mathrm{I} \mathrm{a}$ & $5.37 \mathrm{a}$ & $6.93 \mathrm{a}$ & $7.38 \mathrm{ab}$ & $7.26 \mathrm{a}$ & $3.46 \mathrm{a}$ & $4.17 \mathrm{a}$ & $5.02 \mathrm{abc}$ & $5.52 \mathrm{abc}$ & $4.77 \mathrm{a}$ \\
\hline 5 & $4.31 \mathrm{~b}$ & $4.12 \mathrm{~b}$ & $3.01 \mathrm{~b}$ & $4.18 \mathrm{ab}$ & $4.44 \mathrm{~cd}$ & $3.7 \mathrm{I} a b$ & $1.92 \mathrm{~b}$ & $2.46 \mathrm{~b}$ & $3.16 \mathrm{~cd}$ & $3.28 \mathrm{~cd}$ & $2.62 \mathrm{ab}$ \\
\hline 6 & $4.79 \mathrm{~b}$ & $4.35 \mathrm{~b}$ & $3.13 \mathrm{~b}$ & $4.50 \mathrm{ab}$ & $4.83 \mathrm{bcd}$ & $4.46 \mathrm{ab}$ & $2.09 \mathrm{~b}$ & $2.45 \mathrm{~b}$ & $3.22 \mathrm{bcd}$ & $3.57 \mathrm{bc}$ & $2.95 \mathrm{ab}$ \\
\hline 7 & $7.59 \mathrm{a}$ & $6.76 \mathrm{a}$ & $4.72 \mathrm{a}$ & $6.25 \mathrm{a}$ & $6.54 \mathrm{abc}$ & $6.31 \mathrm{a}$ & $3.11 \mathrm{a}$ & $3.79 \mathrm{a}$ & $4.58 \mathrm{abc}$ & $4.87 \mathrm{abc}$ & $4.10 \mathrm{a}$ \\
\hline
\end{tabular}

Numbers followed by the same letter in the columns do not differ from each other by Tukey test at $5 \%$ probability. Where: provenance I = Ivaí (PR); $2=$ Colombo (PR); 3 = Barão de Cotegipe (RS); 4 = Quedas do Iguaçu (PR); 5 = Pinhão (PR); 6 = Antônio Olinto (PR); 7 = Cascavel (PR). 
TABLE 5 Measured commercial biomass (CB), commercial biomass estimation and productivity score according to sex in an erva-mate provenances and progenies trial located in Ivaí, PR, Brazil.

\begin{tabular}{cccccccc}
\hline & Gender & CB & Eva I & Eva 2 & Eva 3 & Eva 4 & Eva 5 \\
\hline $\begin{array}{c}\text { Commercial } \\
\begin{array}{c}\text { Estimated } \\
\text { biomass }\end{array}\end{array}$ & Male & 13.65 & 11.59 & 7.38 & 9.01 & 10.64 & 10.06 \\
\hline $\begin{array}{c}\text { Productivity } \\
\text { score }\end{array}$ & Male & 13.65 & 4.88 & 5.40 & 6.11 & 7.31 & 6.31 \\
\hline
\end{tabular}

In a general way, the correlation between measured commercial biomass (CB), commercial biomass estimation ( $\mathrm{CBE}$ ) and productivity score (PS) for male and female plants proved to be high. Emphasis is given to commercial biomass estimation in male plants that, except for evaluator 2 , is higher than 0.90 (Table 6).

Based on the definitions of Cohen (1988) and Dancey and Reidy (2006), where correlation values above 0.5 and 0.7 , respectively, may be considered high, we can infer that the indirect assessment, mainly by means of commercial biomass estimation, is highly capable of representing the measured commercial biomass (kg.plant $\left.{ }^{-1}\right)$.

TABLE 6 Correlation between measured commercial biomass (CB), commercial biomass estimation (CBE) and productivity score (grade) according to sex in an erva-mate provenances and progenies trial located in Ivaí, PR, Brazil.

\begin{tabular}{cccc}
\hline \multirow{2}{*}{ Estimation } & Evaluator & \multicolumn{2}{c}{ CB } \\
\cline { 3 - 4 } & & Male & Female \\
\hline \multirow{4}{*}{ CBE I } & $0.93^{*}$ & $0.99^{* *}$ \\
& Eva 2 & $0.54^{\text {ns }}$ & $0.85^{\text {ns }}$ \\
& Eva 3 & $0.97^{* *}$ & $0.80^{\text {ns }}$ \\
& Eva 4 & $0.97^{* *}$ & $0.90^{*}$ \\
& Eva 5 & $0.98^{* *}$ & $0.64^{\text {ns }}$ \\
\hline \multirow{6}{*}{ Grade } & Eva I & $0.8 I^{\text {ns }}$ & $0.96^{* *}$ \\
& Eva 2 & $0.25^{\text {ns }}$ & $0.46^{\text {ns }}$ \\
& Eva 3 & $0.94^{*}$ & $0.89^{*}$ \\
& Eva 4 & $0.88^{\text {ns }}$ & $0.90^{*}$ \\
& Eva 5 & $0.99 * *$ & $0.62^{\text {ns }}$ \\
\hline
\end{tabular}

* and ** significant at $5 \%$ and $1 \%$ error probability, respectively, and "ns" no significant at $5 \%$ of probability by the $F$ test.

Precision in commercial biomass estimation $(\mathrm{CBE})$, or even in scores of productivity tends to increase according to the knowledge of some qualitative and quantitative parameters of the species. Morphotype is among the most influential and, although the scarce information about these in the literature, there are significant differences between them, concerning the morphobiological characteristics.

The morphotype sassafrás presented the largest measured commercial biomass (CB) (kg.plant $\left.{ }^{-1}\right)$, differing only from dull green morphotype (Table 7). In general, the ability of evaluators to estimate the productivity of different morphotypes is proved by comparison of averages among different morphotypes, in which those that showed greater productivity for real commercial biomass, also presented the highest estimated yield.

Characterized by the glossy aspect of limbo in the adaxial face (REISSMANN et al., 2003), the morphotype sassafrás stands out by the compression of its canopy, with naturally reduced leaf fall, increasing their commercial biomass (leaves and fine stems). It is easily identified and has very peculiar canopy architecture, favoring biomass productivity and a suitable target for breeding programs for the species.

A low correlation between measured commercial biomass ( $\mathrm{CB})$, commercial biomass estimation (CBE) and productivity score (PS) was noticed for morphotypes. Only evaluators $I$ and 2 have expressed significant correlation, with prominence for evaluator I, which showed significance among all morphotypes and productivity score (Table 8 ).

Despite the lowest correlation among the variables, the estimations kept the same level of significance among the general averages for each morphotype, i.e., the evaluators have expressed a greater productivity of morphotype sassafrás through the commercial biomass estimation and productivity score.

This way, in spite of the accuracy provided by the direct method with pruning, sorting of the material and weighing of the commercial biomass, it is indispensable to take into account the costs and time required to run it. In the case of extensive areas, with a great number of individuals to be evaluated, the visual estimative can provide excellent results, efficiently replacing the weighing in analysis and selection of higher yield genetic material.

Its use may also be proposed as a low-cost method to predict the productive ability of ervamate plantations, as well as qualitatively defineing this productivity. In addition, these methodologies can be adapted in order to evaluate other characteristics of interest for commercial biomass production of ervamate, as estimation of leaves falling-off and incidence of pests. 
TABLE 7 Measured commercial biomass (CB), commercial biomass estimation (CBE) and productivity score (PS) according to morphotype in an erva-mate provenances and progenies trial located in Ivaí, PR, Brazil.

\begin{tabular}{|c|c|c|c|c|c|c|c|c|c|c|c|}
\hline \multirow{2}{*}{ Morphotype } & \multirow{2}{*}{$\begin{array}{c}\text { Commercial biomass } \\
\mathrm{kg} \cdot \text { plant }^{-1}\end{array}$} & \multicolumn{5}{|c|}{ Commercial biomassa estimation } & \multicolumn{5}{|c|}{ Productivity Score } \\
\hline & & Eva I & Eva 2 & Eva 3 & Eva 4 & Eva 5 & Eva I & Eva 2 & Eva 3 & Eva 4 & Eva 5 \\
\hline $\mathrm{I}$ & $9.12 \mathrm{ab}$ & $7.61 \mathrm{ab}$ & $5.29 \mathrm{ab}$ & $7.04 \mathrm{ab}$ & $7.65 \mathrm{ab}$ & $6.89 \mathrm{ab}$ & $3.57 \mathrm{ab}$ & $4.17 \mathrm{ab}$ & $5.10 \mathrm{ab}$ & $5.66 \mathrm{ab}$ & $5.09 \mathrm{a}$ \\
\hline 2 & $7.85 \mathrm{ab}$ & $6.89 \mathrm{ab}$ & $4.89 \mathrm{ab}$ & $6.50 \mathrm{~b}$ & $6.84 \mathrm{ab}$ & $6.59 \mathrm{ab}$ & $3.17 \mathrm{ab}$ & $3.86 \mathrm{ab}$ & $4.73 \mathrm{ab}$ & $5.10 \mathrm{ab}$ & $4.30 \mathrm{ab}$ \\
\hline 3 & $7.19 b$ & $6.41 \mathrm{~b}$ & $4.53 b$ & $6.03 b$ & $6.49 \mathrm{~b}$ & $6.01 \mathrm{~b}$ & $2.92 b$ & $3.59 b$ & $4.42 b$ & $4.77 b$ & $3.97 \mathrm{~b}$ \\
\hline 4 & $10.51 \mathrm{a}$ & $8.77 \mathrm{a}$ & $5.92 \mathrm{a}$ & $7.70 \mathrm{a}$ & $8.56 \mathrm{a}$ & $7.97 \mathrm{a}$ & $3.91 \mathrm{a}$ & $4.50 \mathrm{a}$ & $5.46 \mathrm{a}$ & $6.19 \mathrm{a}$ & $5.04 \mathrm{a}$ \\
\hline
\end{tabular}

Numbers followed by the same letter in the columns do not differ from each other by the Tukey test at $5 \%$ probability.

TABLE 8 Correlation between measured commercial biomass (CB), commercial biomass estimation (CBE) and productivity score (PS) due to morphotype in an erva-mate provenances and progenies trial located in Ivaí, PR, Brazil.

\begin{tabular}{|c|c|c|c|c|c|}
\hline & & \multicolumn{4}{|c|}{ Commercial biomass } \\
\hline & & Gray & Dark green & Dull green & Sassafrás \\
\hline \multirow{5}{*}{ CBE } & Eva I & $0.98 * *$ & $0.93 *$ & $0.84^{\mathrm{ns}}$ & $0.86^{\text {ns }}$ \\
\hline & Eva 2 & $0.97^{* *}$ & $0.67^{\mathrm{ns}}$ & $0.59^{\text {ns }}$ & $0.80^{\mathrm{ns}}$ \\
\hline & Eva 3 & $-0.24^{\mathrm{ns}}$ & $-0.19^{\mathrm{ns}}$ & $0.27^{\mathrm{ns}}$ & $0.5 \mathrm{I}^{\mathrm{ns}}$ \\
\hline & Eva 4 & $0.47 \mathrm{~ns}$ & $-0.02^{\mathrm{ns}}$ & $0.38^{\mathrm{ns}}$ & 0.69 ns \\
\hline & Eva 5 & $-0.45^{\mathrm{ns}}$ & $-0.43^{\text {ns }}$ & $0.14^{\mathrm{ns}}$ & $0.40^{\mathrm{ns}}$ \\
\hline \multirow{5}{*}{ PS } & Eva I & $0.97 * *$ & $0.89 *$ & $0.90 *$ & $0.95 *$ \\
\hline & Eva 2 & $0.91 *$ & $0.64^{\mathrm{ns}}$ & $0.25^{\mathrm{ns}}$ & $0.62^{\text {ns }}$ \\
\hline & Eva 3 & $-0.08^{\text {ns }}$ & $-0.12^{\mathrm{ns}}$ & $0.35^{\mathrm{ns}}$ & $0.66^{\mathrm{ns}}$ \\
\hline & Eva 4 & $0.33^{\text {ns }}$ & $0.07^{\mathrm{ns}}$ & $0.35^{\text {ns }}$ & $0.70^{\mathrm{ns}}$ \\
\hline & Eva 5 & $-0.40^{\text {ns }}$ & $-0.24^{\mathrm{ns}}$ & $0.08^{\text {ns }}$ & $0.38^{\text {ns }}$ \\
\hline
\end{tabular}

* and ** significant at $5 \%$ and $1 \%$ error probability, respectively, and "ns" no significant at $5 \%$ of probability by the $F$ test.

\section{CONCLUSIONS}

The methods evaluated are efficient to estimate commercial biomass. The highest correlations were verified in the general analysis of the averages. The evaluators demonstrated expertise in estimating, efficiently expressing the largest productivity determined by comparing the averages among provenances, sex and morphotypes. The commercial biomass estimation is the best methodology for estimating commercial biomass in adult erva-mate plants. This methodology allows the farmer to more easily identify the most productive genotypes and select the matrices trees for seeds collection or cloning.

\section{ACKNOWLEDGMENTS}

This work is supported by the Brazilian Agricultural Research Corporation (Embrapa Florestas). We thank to Chimarrão Bitumirim Indústria e Comércio de ervamate Ltda. for all the support on the trial conduction and field evaluations.

\section{REFERENCES}

BASTOS, M. C.; REISSMANN, C. B.; KESEKER, J. F.; PAULETTI, V.; GAIAD, S. ; STURION, J. A. Mineral content of young leaves of yerba mate. Pesquisa Florestal Brasileira, v.34, n.77, p. 63-7I, 2014.

BORILLE, A. M. W.; REISSMANN, C. B.; FREITAS, R. J. S. de. Relação entre compostos fotoquímicos e o nitrogênio em morfotipos de erva-mate (llex paraguariensis St. Hil.). Boletim Centro de Pesquisa de Processamento de Alimentos, v. 23, n. I, p. I83-198, 2005.

CARDOZO JUNIOR, E.L.; DONADUZZI, C.M.; FERRARESEFILHO, O.; FRIEDRICH, J.C.; GONELA, A.; STURION, J.A. Quantitative genetic analysis of methylxanthines and phenolic compounds in mate progenies. Pesquisa Agropecuária Brasileira, v.45, n.2, p.171-177, 2010.

CARDOZO JUNIOR, E. L.; MORAND, C. Interest of mate (Ilex paraguariensis A. St.-Hil.) as a new natural functional food to preserve human cardiovascular health. A review. Journal of Functional Foods, v. 21, p. 440-454, 2016.

CARON, B.O.; SCHMIDT, D.; MANFRON, P. A.; BEHLING, A.; ELOY, E; BUSANELLO, C. Eficiência do uso da radiação solar por plantas llex paraguariensis A.St. Hil. cultivadas sob sombreamento e a pleno sol. Ciência Florestal. v.24, n. 2, p. 257-265, 2014.

COHEN, J. Statistical power analysis for the behavioral sciences. Hillsdale, NJ, Erlbaum, 1988. 474p.

CUNHA, W.G.; RAMALHO, M.A.P.; ABREU, Â.F.B. Selection aiming at upright growth habit of common bean with carioca type grains. Crop Breeding and Applied Biotechnology, v.5, p.379-386, 2005.

DANCEY, C.; REIDY, J. Estatística Sem Matemática para Psicologia: Usando SPSS para Windows. Porto Alegre, Artmed, 2006. 608p.

FERREIRA, A.C.M. VER: uma revisão sobre a percepção visual. REHUTEC, v.5, n.I, 15 p., 2016.

IAPAR. Cartas Climáticas do Estado do Paraná. Disponível em: <http://www.iapar.br/modules/conteudo/ conteudo.php?conteudo $=597>$. Acesso em: 25 Abr. 2016.

JANSSENS, M. J. J.SCHERER, A. R. Uso de morfotipos para la seleccion de llex paraguariensis con gusto deseable in Missiones. In: Proceedings of 5th South-American Congress in Yerba-mate. Pousadas: INYM, 20I I, p. 29-30. 
MENEZES JÚNIOR, J. A. N., RAMALHO, M. A. P. ABREU, A. F. B. Seleção recorrente para três caracteres do feijoeiro. Bragantia, v. 67, n. 4, p. 833-838, 2008.

OLIVA, E. V.; REISSMANN, C. B.; GAIAD, S.; OLIVEIRA, E. B.; STURION, J. A. Composição nutricional de procedências e progênies de erva-mate (Ilex paraguariensis St. Hil.) cultivadas em latossolo vermelho distrófico. Ciência Florestal, v. 24, n. 4, p. 793-805, 2014.

PETZOLD, A.; PFEIFFER, T.; JANSEN, F.; EUSEMANN, P.; SCHNITTLER, M. Sex ratios and clonal growth in dioecious Populus euphratica Oliv., Xinjiang Prov., Western China. Trees, v. 27, n. 3, p. 729-744, 2013.

RAKOCEVIC, M.; STURION, J.A.; MEDRADO, M. J. S.; LAVORANTI, O. J.; MOSELE, S.H.; VALDUGA, A.T. Propriedades ecofisiológicas e produtivas como ferramenta para melhoramento genetico de erva-mate (Ilex paraguariensis St. Hil). Boletim de Pesquisas Florestal, $n$. 5I, p. I09-I30, 2005.

RAKOCEVIC, M.; MEDRADO, M.J.S.; LAVORANTI, O.J.; VALDUGA, A.T. Quality of yerba-mate leaves originating from male and female plants. Pesquisa Florestal Brasileira, v.54, p.7I-83, 2007.

RAKOCEVIC, M.; MEDRADO, M.J.S.; MARTIM, S.F.; ASSAD, E.D. Sexual dimorphism and seasonal changes of leaf gas exchange in the dioecious tree llex paraguariensis grown in two contrasted cultivation types. Annals of Applied Biology, v. I54, n.2, p. 29I-30I, 2009.

RAKOCEVIC, M.; COSTES, E.; ASSAD, E. D. Structural and physiological sexual dimorphism estimated from three-dimensional virtual trees of yerba-mate (llex paraguariensis) is modified by cultivation environment. Annals of Applied Biology, v. 159, n.2, p. I78-191, 201 I.

RAMIREZ-MARES, M. V.; KOBAYASHI, H.; MEJIA, E. G.de Inhibitory effect of Camellia sinensis, llex paraguariensis and Ardisia compressa tea extracts on the proliferation of human head and neck squamous carcinoma cells. Toxicology Reports, v.3, p. 269-278, 2016.

REISSMANN, C. B., DÜNISCH, O.BOEGER, M. R. Beziehung Zwischen Ernährungsbiologischen ( $\mathrm{Fe}, \mathrm{Mn}, \mathrm{Ca})$ und Strukturellen Merkmalen Ausgewählter Morphotypen Der Mate-Pflanze (Ilex paragueriensis St. Hil). In: HÜTTL, R. F. (Org.). Boden, Wald und Wasser. I. ed. Germany: KLUVER, 2003, p. |46-I7I.

RIBEIRO, N.D.; CARGNELUTTI FILHO, A.; POERSCH, N.L.; ROSA, D.P. Critério de seleção indireta para a produtividade de grãos em feijão. Ciência Rural, v. 40, n. 4, p. 986-989, 2010.
ROBINSON, K.M.; DELHOMME, N.; MÄHLER, N.; SCHIFFTHALER, B.; ÖNSKOG, J.; ALBRECTSEN, B.R.; STREET, N.R. Populus tremula (European aspen) shows no evidence of sexual dimorphism. BMC plant biology, v. I4, n. I, p. I-I4, 2014

SANTIN, D.; WENDLING, I.; BENEDETTI, E. L.; MORANDI, D.; DOMINGOS, D. M. Sobrevivência, crescimento e produtividade de plantas de erva-mate produzidas por miniestacas juvenis e por sementes. Ciência Florestal, v. 25 , n. 3, p. 57I-579, 2015.

SANTOS, H.G.; JACOMINE, P.K.T.; ANJOS, L.H.C.; OLIVEIRA, V.A.; OLIVEIRA, J.B.; COELHO, M.R.; LUMBRERAS, J.F.; CUNHA, T.J.F. (Ed.). Sistema brasileiro de classificação de solos. Rio de Janeiro: Embrapa Solos, 2006. 306p.

SANTOS, E. C. S.; BICCA, M. A.; BLUM-SILVA, C. H.; COSTA, A. P. R.; SANTOS, A. A. dos; SCHENKEL, E. P.; FARINA, M.; REGINATTO, F. H.; LIMA, T. C. M. de Anxiolytic-like, stimulant and neuroprotective effects of llex paraguariensis extracts in mice. Neuroscience, v. 292, p. 13-21, 2015.

SILVEIRA, P.; KOEHLER, H.S.; SANQUETTA, C. R.; ARCE, J.E. $O$ estado da arte na estimativa de biomassa e carbono em formações florestais. Floresta, v.38, n. I, p. I85-206, 2008.

SILVEIRA, T. F. F. da; MEINHART, A. D.; COUTINHO, J. P.; SOUZA,T. C. L. de; CUNHA, E. C. E.; MORAES, M. R. de; GODOY, H. T. Content of lutein in aqueous extracts of yerba mate (Ilex paraguariensis St. Hil). Food Research International, v.82, p. I65-I7I, 2016.

STURION, A. J.; RESENDE, M. D. V. de; MENDES, S. Proporção de sexo e produtividade de massa foliar em erva-mate (llex paraguariensis St. Hil). Boletim de Pesquisa Florestal, n. 30/31, p.23-31, 1995.

STURION, J. A.; RESENDE, M.D.V. de Seleção de progênies de erva-mate (Ilex paraguariensis St. Hil.) para produtividade, estabilidade e adaptabilidade temporal de massa foliar. Boletim de Pesquisa Florestal, n.50, p.37-5I, 2005.

STURION, J.A.; RESENDE, M.D.V. Melhoramento genético da erva-mate. Colombo: Embrapa Florestas, 2010. 274 p.

VALDUGA, A.T.; GONÇALVES, I. L.; DARTORA, N.; MIELNICZKI-PEREIRA, A. A.; SOUZA, L. M. de Phytochemical profile of morphologically selected yerbamate progênies. Ciência e Agrotecnologia. v. 40, n .I, p. II4-I20, 2016.

WENDLING, I. Propagação vegetativa de erva-mate (llex paraguariensis): estado da arte e tendências futuras. Colombo - PR: Embrapa Florestas, (Série Documentos, 9I). 46p. 2004. 